\title{
ELASTICITY OF SUBSTITUTION IN THE MANUFACTURING SECTOR IN THE CZECH REPUBLIC
}

\section{Cristina Procházková Ilinitchia (iD, Anastasie Pustovalováa, David Procházkaa iD}

\begin{abstract}
The paper estimates the elasticity of substitution between capital and labour under biased technical change in the manufacturing sector in the Czech Republic. We use a dataset covering the period 1995-2019 and a 2-digit industry level, from NACE10 to NACE33. We find industry-level elasticities to be 0.19 and 0.94 ; therefore, labour and capital seem to be gross complements rather than substitutes across all manufacturing sectors. In the core industries of the Czech manufacturing sector, the elasticity is below average. Even if these core sectors have high and increasing labour costs (except NACE29, where the labour costs are below average), they do not replace labour with capital at a higher pace. This cannot be explained by the direction of technological bias because it is not capital-augmenting. On the other hand, our findings are in line with the literature, as most studies on transition countries report low estimates for the elasticity.
\end{abstract}

Keywords: elasticity of substitution, capital-labour substitution, Czech Republic, manufacturing sector, technological change

JEL Classifications: D24, E23, O14

\section{Introduction}

During the last decades, the unemployment rate in the Czech Republic has oscillated around $6 \%$, hitting a maximum of $8.8 \%$ in 2000 and being on a path of significant decrease after 2016, reaching 2\% only in 2019 (CZSO, 2020). There is a long-lasting deficit of labour supply perceived by Czech companies, which can be a limiting factor to their development. Low unemployment rates are furthermore accompanied by another negative fact: labour productivity increases at a slower rate than wages. This can lead to Czechia's decreasing international competitiveness. One way to respond to this development is substituting

\footnotetext{
* This paper was written as part of IGA project no. F2/49/2019, "Global value chains and technological changes: the impact on world economy", Prague University of Economics and Business.

a Prague University of Economics and Business, Czech Republic

E-mail: Cristina.ilinitchi@vse.cz; anastasie.pustovalova@gmail.com; prochazd@vse.cz
} 
work with capital. There is a current pressure to implement Industry 4.0 elements and move upwards in Global Value Chains (GVC), which is especially relevant for the Czech Republic as a country heavily relying on manufacturing and currently placed in the middle of GVC (Vlčková, 2018).

Substituting factors of production may not be so simple, though. In some cases, factors may be complements and cannot be replaced easily. Economic theory uses the elasticity of substitution as a measure of substitutability between labour and capital, and it is designated as $\sigma$ (sigma) in the literature. Early studies found $\sigma$ to be around 1, but most recent studies present more mixed results. Estimates appear to be very sensitive to the methodology and data used. Most papers estimate country-level $\sigma$, although it seems logical that substantial differences between sectors should exist. There is very little academic research on the direction and magnitude of the substitutability between labour and capital in the Czech Republic. To our knowledge, there are very few studies that estimate country-level $\sigma$ (Szomolányi et al., 2017) and there is no study that estimate sector-level $\sigma$ for the Czech Republic.

The aim of our paper is to estimate the industry-level elasticities of substitution between labour and capital $(\sigma)$ for the manufacturing sector in the Czech Republic, namely from NACE10 to NACE33. We consider this relevant especially in the context of heavy reliance of the Czech economy on these sectors. The share of these sectors in total employment is $28 \%$ and the share in total gross value added is $30 \%$ (CZSO, 2020). In our study, we use a dataset covering a period of 25 years, from 1995 to 2019.

\section{Theoretical Background and Empirical Estimations}

A rich body of literature studying the elasticity of substitution $(\sigma)$ between labour and capital has emerged after Arrow et al. (1961) developed an explicit CES (Constant Elasticity of Substitution) production function (see Equation 1):

$$
Y_{t}=A_{t}\left[\pi K_{t}^{\frac{\sigma-1}{\sigma}}+(1-\pi) L_{t}^{\frac{\sigma-1}{\sigma}}\right]^{\frac{\sigma}{\sigma-1}}
$$

where $Y_{t}$ is the real output, $\pi$ is a distribution parameter denoting the share of capital in the output, $A_{t}$ is an efficiency parameter (Hicks-neutral technological shifter) and $K_{t}$ and $L_{t}$ are the amounts of capital and labour. Under perfect competition, capital and labour are paid by their marginal products, so the elasticity of substitution is given by the change in proportion of capital and labour due to a change in the factor price ratio (see Equation 2).

$$
\sigma=\frac{d \log \left(\frac{K}{L}\right)}{d \log \left(\frac{w}{r}\right)}
$$


when $\sigma=1$, the CES production function is defined as the Cobb-Douglas function. If $\sigma>1$, the production factors are gross substitutes, and accordingly, if $\sigma<1$, they are gross complements. This would imply that values of $\sigma$ above unity could be a source of continual growth, as the scarce and abundant factors of production could easily be replaced.

Early studies concluded that $\sigma$ and technological bias could not be assessed simultaneously and adopted a Hicks-neutral specification. More recent studies take into consideration biased technological progress ${ }^{1}$. In this sense, the original CES production function can be extended to capture technological progress (as specified in Leon-Ledesma, 2010; Antras, 2004) and takes the following form (see Equation 3):

$$
Y_{t}=C\left[\pi\left(A_{t}^{K} K_{t}\right)^{\frac{\sigma-1}{\sigma}}+(1-\pi)\left(A_{t}^{L} L_{t}\right)^{\frac{\sigma-1}{\sigma}}\right]^{\frac{\sigma}{\sigma-1}}
$$

where $A_{t}^{K}$ and $A_{t}^{L}$ are measures for capital- and labour-augmenting technological progress (index of capital- and labour-augmenting efficiency, respectively), though being able to capture technological bias (e.g., a situation where $A_{t}^{K} \neq A_{t}^{K}$ ). The bulk of the literature usually assumes specific functions for factor-augmenting technical progress, as for example $A_{t}^{K}=A_{0}^{K} e^{\gamma_{K} t}$ and $A_{t}^{L}=A_{0}^{L} e^{\gamma_{L} t}$, where $\gamma_{K}$ and $\gamma_{L}$ reflect growth in technological progress associated with capital and labour, respectively, and $t$ is a time trend. The underlying assumption is that the indices $A_{t}^{K}$ and $A_{t}^{L}$ grow at constant rates. Table 1 summarizes the types of technological progress that can be considered.

Table 1: Types of technical progress

\begin{tabular}{l|l}
\hline$\gamma K>0 ; \gamma L>0 ; \gamma K=\gamma L$ & Hicks-neutral technological progress \\
\hline$\gamma K>0 ; \gamma L=0$ & Harrod-neutral technological progress \\
\hline$\gamma K>0 ; \gamma L>0$ & Solow-neutral technological progress \\
\hline$\gamma K>0 ; \gamma L>0 ; \gamma K>\gamma L$ & Capital-saving biased technological progress \\
\hline$\gamma K>0 ; \gamma L>0 ; \gamma K<\gamma L$ & Labour-saving biased technological progress \\
\hline
\end{tabular}

Source: Authors' own summarization

1 If we assume two factors of production, labour and capital, technological bias can have two directions: labour-augmenting technological bias and capital-augmenting technological bias. Augmenting is a technical progress that increases the effectiveness of the input. Augmenting should not be confused with deepening, which denotes the relative share of the amounts of factors of production. 
Allowing for biased technological progress is very important. As Klump et al. (2012) summarize, different combinations of technological bias and $\sigma$ can lead to similar outcomes in terms of factor income. For instance, if $\sigma>1$ (labour and capital are gross substitutes), a labour-augmenting technological bias will favour labour. Returns to labour relative to returns to capital will increase; therefore, the share of labour and capital income will increase as well. If $\sigma<1$ (labour and capital are gross complements), a labour-augmenting technological bias will favour capital (e.g., the share of capital income in labour income will increase). Table 2 offers a summarization of these outcomes. The idea is that, for example, gross complementarity between factors and capital-augmenting technological bias will lead to a different outcome than gross complementarity and labour-augmenting technological bias. On the other hand, misspecification of technological progress can lead to significant bias in the estimation of $\sigma$.

Table 2: Implications of value of $\sigma$ and different directions of technological bias

\begin{tabular}{l|l|l}
\hline Value of elasticity & Direction of technological bias & \multicolumn{1}{|c}{ Outcome in terms of income share } \\
\hline$\sigma<1$ & Capital-augmenting & Increase in income share of labour \\
\hline$\sigma<1$ & Labour-augmenting & Increase in income share of capital \\
\hline$\sigma>1$ & Capital-augmenting & Increase in income share of capital \\
\hline$\sigma>1$ & Labour-augmenting & Increase in income share of labour \\
\hline
\end{tabular}

Source: Authors' own summarization

The relevance of technological bias is also supported by empirical evidence. For instance, Antras (2004) shows that adoption of Hicks neutrality biases $\sigma$ estimations towards unity. As Leon-Ledesma et al. (2010) point out, the origin of factor income movements is very important in terms of their different implications (growth accounting, inequality, calibration in business cycle models, public policy issues, etc.). Acemoğlu (2003) investigates the nature of technological change and concludes that technological progress is labour-augmenting on a balanced-growth path, while it is capital-augmenting on a transitional path. His analysis of direction of technological bias has many implications in areas as tax policies, trade, impact of large macroeconomic shocks, etc. A widely cited study by Karabarbounis and Neiman (2014) concludes that the labour share in developed economies had been constantly decreasing over the past 35 years. They explain these observations by $\sigma \neq 1$ and biased factor-augmenting technical change.

Empirical estimations of $\sigma$ cover a wide range of values, both below and over unity. Arrow et al. (1961) estimated $\sigma$ for the USA for 1909-1949 and found it to be 0.6. Later studies using US data seem to support gross complementarity between US labour and capital data 
(Berndt, 1976; Antras, 2004; Chirinko, 2008; Leon-Ledesma et al., 2010; Klump et al., 2007; Klump et al., 2012; Cantore et al., 2015).

Cross-country estimates and estimates focusing on other than US data provide more mixed results. Studies assuming Hicks neutrality often find values of $\sigma$ above unity. Duffy and Papageorgiou (2000) use a sample of 82 countries over a period of 28 years and find $\sigma$ to be above unity in average (around 1.4), the estimates for poorer countries being lower than in richer countries. Karabarbounis and Neiman (2014) obtain an estimate around 1.25. Berthold et al. (2002) adopt the Harrod neutrality assumption and obtain a value of 1.45 for Germany and 2.01 for France, which are higher than their estimates for the USA (1.15). Studies adopting a factor-augmenting approach find estimates below unity for the Euro area (Klump et al., 2008). On the other hand, Jalava et al. (2006) argue that they found similar results for Finland and the USA (0.5) and they state that $\sigma$ is therefore not dependent on specific structure of economic institutions but probably reflects more general aspects of technology and production. Lee and Tcha (2004) find a value of 0.5 for transition countries, which is in line with earlier studies on transition economies, which also find low estimates of $\sigma$ (Weitzman, 1970; Easterly and Fisher, 1995). Mallick (2012) estimates the elasticity for 90 countries and finds support for the complementarity of labour and capital, while Raurich et al. (2012) find a value above one for Spain. Sala and Trivin (2018) present more recent estimates and obtain values below unity in the OECD countries. They also conclude that in these countries, the elasticity increases along with the degree of globalization; but it decreases with the level of technology.

Knoblach et al. (2020) summarize the estimates from 71 studies on the US economy published between 1961 and 2017 and find that most estimates are in the interval $(0.45 ; 0.87)$ for the aggregate level and the values are similar for manufacturing industries. Gechert et al. (2019) run a meta-analysis of 121 studies and find a weighted mean of 0.8 for $\sigma$. Both studies find $\sigma$ to be bimodal (with two peaks, one peak near 1 and another peak near 0). Estimations at industry and firm level are generally slightly lower in their values. Figure 1 presents the distribution of the estimations in these two studies.

Based on previous research, we expect to obtain industry-level estimates of the elasticity of substitution between labour and capital below one. Furthermore, considering that the Czech Republic is still influenced by its transition path, the values of $\sigma$ would probably be rather low. On the other hand, as de La Grandville (1989) states, developing economies should therefore have higher values of elasticity, because change in prices of factors of production are quickly reflected in changes of product. The Czech Republic is not a developing country, but we should be expecting lower values than in countries with a higher level of development. Finally, in sectors with high labour costs, the elasticity should be higher, reflecting a higher pressure to reduce labour costs. The ongoing technological changes, often covered by the term Industry 4.0, should boost the elasticity values. 
Figure 1: Histograms with values of $\sigma$ : meta-analysis by Knoblach et al. (2020) (top figure) and Gechert et al. (2019) (bottom figure)

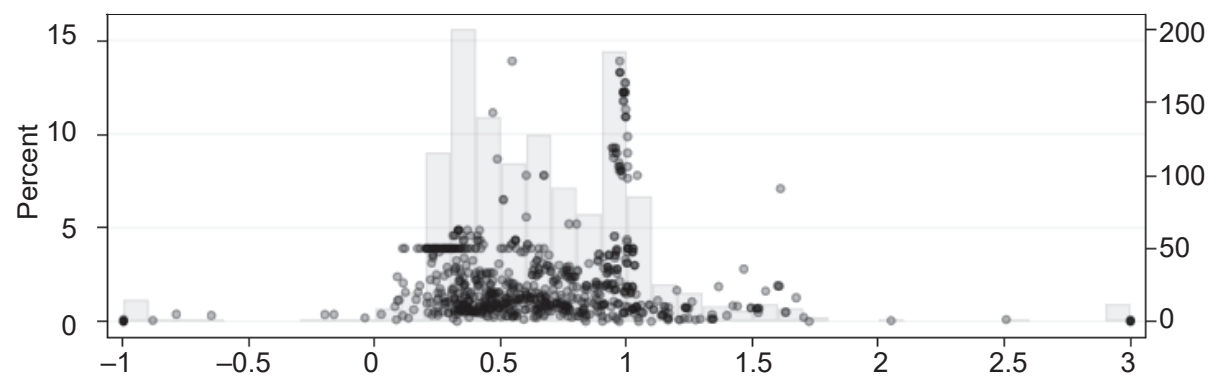

Elasticity of U.S. factor substitution - aggregate economy estimates

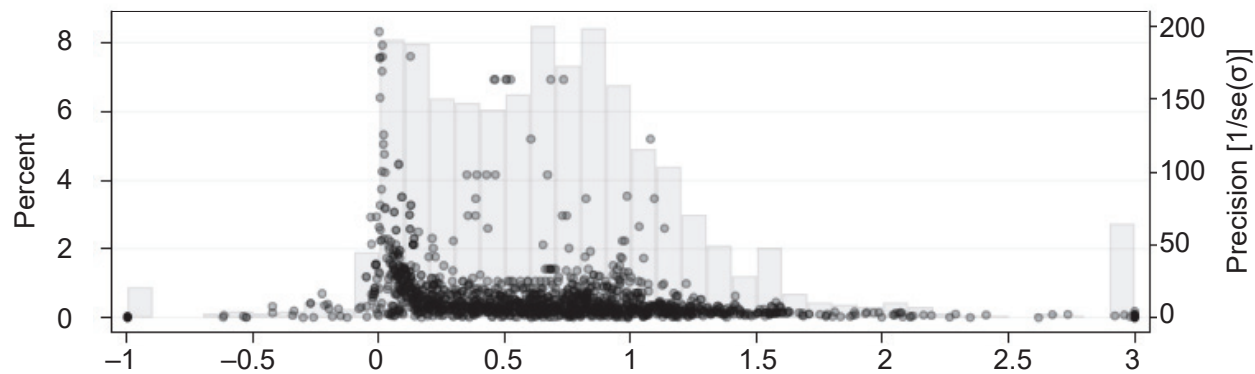

Elasticity of U.S. factor substitution - industry estimates

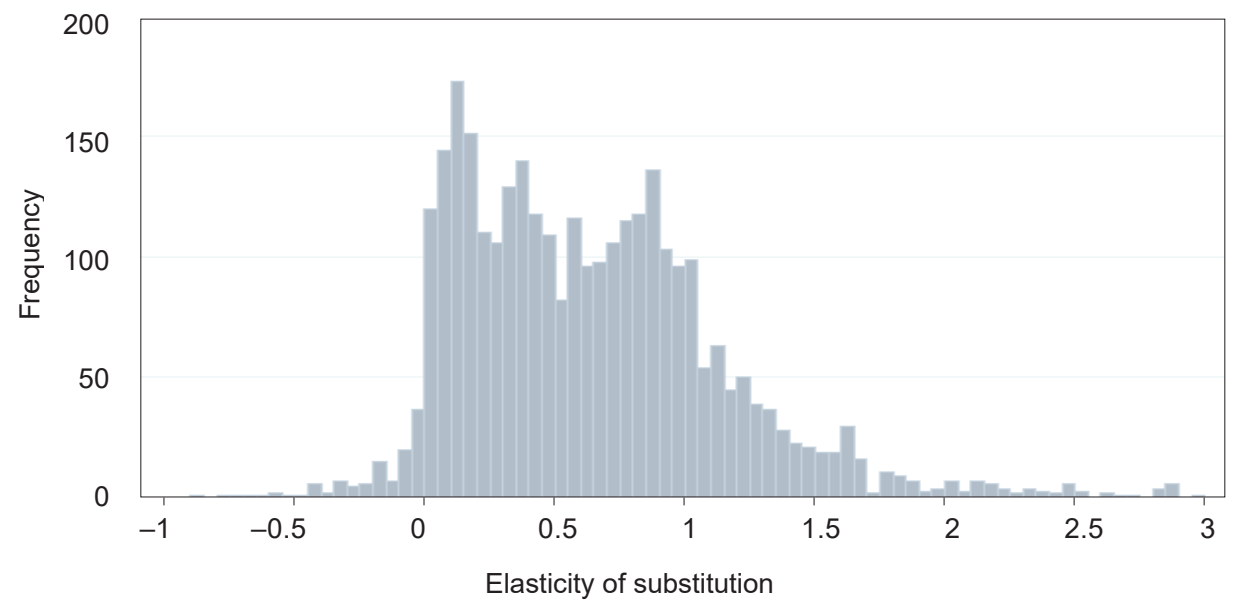

Source: Knoblach et al. (2020); Gechert et al. (2019) 


\section{Methodology and Data}

\subsection{Methodology}

We adopt a CES production function as specified in Arrow et al. (1961) and expand it with biased technological progress (Equation 3 in the previous section). As discussed earlier, the bulk of literature assumes that the indices $A_{t}^{K}$ and $A_{t}^{L}$ grow at constant rates, which are captured by $\gamma_{K}$ and $\gamma_{K}$, so the production function becomes (Equation 4):

$$
Y_{t}=\left[\delta\left(A_{0}^{K} e^{\gamma_{K} t} K_{t}\right)^{\frac{\sigma-1}{\sigma}}+(1-\delta)\left(A_{0}^{L} e^{\gamma_{L} t} L_{t}\right)^{\frac{\sigma-1}{\sigma}}\right]^{\frac{\sigma}{\sigma-1}}
$$

In our research, we use data on evolution of factor share in total factor productivity published by the AMECO and use it as a measure for time-varying $A_{t}^{K}$ and $A_{t}^{L}$. Compared to previous studies, we do not have to adopt the assumption of these indices growing at constant rates; therefore, we can rely on the CES written in Equation (3). However, the disadvantage of our approach is that we do not have industry-level estimates, so we will assume that the growth rates are equal across sectors. After applying the first-order conditions to Equation (3) with respect to capital and labour, and combining the FOC with respect to capital and the FOC with respect to labour, we obtain the final estimation form $^{2}$ (Equation 5):

$$
\log \left(\frac{K_{t}}{L_{t}}\right)=\sigma \log \left(\frac{\pi}{1-\pi}\right)+\sigma \log \left(\frac{w_{t}}{r_{t}}\right)+(1-\sigma) \log \left(\frac{A_{t}^{L}}{A_{t}^{K}}\right)+\varepsilon_{t}
$$

where $w_{t}$ is the price of labour services and $r_{t}$ is the price of capital services.

\subsection{Data}

The estimation of Equation 5 requires data on the stock of capital and labour, prices of labour and capital services and data necessary to measure the variables and $A_{t}^{L}$.

We get most of our data from the CSZO Database of National Accounts. An alternative would be to use the WIOD Socio Economic Accounts, which also provides sector-level data. The reason why we prefer the CSZO database is because it covers a longer period of time and does not aggregate some of the sectors as the WIOD does. Another option would be the EU-KLEMS database, which also focuses on productivity issues and does provide sector-level data with some aggregation. However, it covers a shorter period and

2 Similar approaches are discussed in Antras (2004), Leon-Ledesma et al. (2010) or Gechert et al. (2019). 
the construction of the indicators that would come into consideration does not suit our model. In our analysis, we cover the period 1995-2019 at a NACE-2 industry level. We will use data from the EU-KLEMS database only as a robustness check for the price of capital services.

The detailed construction of our variables is as follows. There are two options when it comes to measuring the labour stock $\left(L_{t}\right)$ : the first one is the number of persons or FTE (full-time equivalents), the other is the number of hours worked. Data are further usually broken down into employed persons (or hours) and self-employed persons (or hours). We construct our estimate for the labour stock by summing up employed and self-employed labour and we use the number of hours worked. We consider that it reflects more accurately the amount of labour engaged in the production process (see also Herrendorf et al., 2015; Klump et al., 2012).

The costs of labour services $\left(w_{t}\right)$ are calculated as the share of compensations to employees and number of hours worked (by employed persons). We follow the literature by assuming that the compensations to self-employed and employed persons do not differ significantly. Compensations to employees consist of employer contributions for social insurance, wages and remunerations. Items such as taxes and subsidies related to employment, as well as employee benefits, are not included.

To measure the stock of capital $\left(K_{t}\right)$, we use data on fixed assets at constant prices. To measure the price of capital services $\left(r_{t}\right)$, we employ two approaches. The first one is to calculate the price of capital services according to Equation 6:

$$
r_{i, t}=\frac{\left(1-\theta_{i, t}\right) Y_{i, t}}{K_{i, t}}
$$

where $Y_{i, t}$ is the real output and is measured as the gross value added (GVA) at constant prices, and $\theta_{i, t}$ is the share of labour income in sector $i$ 's value added (VA). We calculate $\theta_{i, t}$ as the share of labour compensation on GVA at current prices. This approach can often be encountered in papers which do not use US data (Herrendorf et al., 2015, Kreuser et al., 2015, etc.) and the same approach is used by the EU-KLEMS and WIOD databases when estimating capital costs. Papers using US data might construct the price of capital services differently due do different data availability.

However, to make sure that our calculations of price of capital services are accurate, we also employ a second approach. In this second approach we calculate the price of capital services as the share of variable CAP, available in the EU-KLEMS database, and the fixed assets at current prices, retrieved from the CSZO. This second approach to measuring the price of capital services has two limitations: the variable CAP is available only until 2017, and the sectoral breakdown is not fully available, as some NACE sectors are aggregated (NACE10-12, NACE13-15, NACE16-18, NACE22-23, NACE24-25, 
NACE29-30 and NACE31-33). In such cases, we assumed that the price of capital services is the same within the aggregated groups; however, this will be kept in mind when comparing the results of these two approaches. In the Results section, Model 1 and Model 2 will denote the first and second approach to price measurement, respectively. In order to measure the variables $A_{t}^{K}$ and $A_{t}^{L}$, we use data from the AMECO database, which publishes information on labour and capital share in total factor productivity on a yearly basis. Table 3 presents the summary statistics for all above-mentioned variables for the years 1995 and $2017^{3}$ :

Table 3: Summary statistics for the stock of capital and labour, prices of labour and capital services (aggregate values for NACE10-33)

\begin{tabular}{|c|c|c|c|c|c|}
\hline 1995 & $\min$ & median & $\max$ & mean & sd \\
\hline$K$ & 7,327 & 29,470 & 186,185 & 47,205 & 44,652 \\
\hline$L$ & 7,882 & 87,934 & 296,141 & 101,708 & 75,907 \\
\hline$r(\mathrm{CZSO})$ & 0.053 & 0.184 & 0.515 & 0.199 & 0.111 \\
\hline$r$ (EU-KLEMS) & 0.086 & 0.217 & 0.647 & 0.222 & 0.117 \\
\hline$w$ & 0.055 & 0.075 & 0.117 & 0.080 & 0.018 \\
\hline 2017 & $\min$ & median & $\max$ & mean & sd \\
\hline$K$ & 5,499 & 63,316 & 484,731 & 105,471 & 107,563 \\
\hline$L$ & 2,139 & 69,452 & 359,311 & 101,437 & 96,942 \\
\hline$r($ CZSO) & 0.119 & 0.225 & 0.698 & 0.251 & 0.121 \\
\hline$r$ (EU-KLEMS) & 0.033 & 0.211 & 0.350 & 0.202 & 0.073 \\
\hline$w$ & 0.154 & 0.291 & 0.569 & 0.289 & 0.091 \\
\hline
\end{tabular}

Source: Authors' own calculations based on CSZO (2020) and EU-KLEMS (2020)

Finally, in order to be able to apply Equation (5), we need to verify whether the Czech manufacturing sector meets the perfect competition requirements. In order to assess the fulfilment of this condition, we adopt an empirical approach and look into several aspects: number and size of firms (the higher the number of firms and the smaller the firms, the higher the competition level), trade openness (manufacturing products are in their vast majority tradeable goods; therefore, the higher the trade openness, the higher the competition faced by domestic firms) and probability of market distortions (government policies; in the case of sector-oriented policies, markets might be distorted and pulled farther from perfect competition).

3 Untabulated results for each year or for each NACE are available upon request. 
Out of the 24 manufacturing sectors, only three report a number of firms under 100 (NACE12 with 7 firms, NACE19 with 26 firms and NACE21 with 93 firms). Out of the remaining 21 sectors, 19 report over 1,000 firms and 5 report over 10,000 firms (NACE14, NACE16, NACE25, NACE27 and NACE33) ${ }^{4}$ (CSZO, 2020). The vast majority (92.9\%) of firms in the Czech manufacturing sector are microfirms, $6.6 \%$ are SMEs and $0.5 \%$ are large firms (MPO, 2020).

In terms of trade openness, the Czech Republic reported in 2019 a value of $143 \%$ of trade/GDP, ranking $26^{\text {th }}$ worldwide (WB, 2021). At sector level, the highest trade turnovers were in NACE24-29, 20 and 22 (MPO, 2020). These 7 sectors account for $74 \%$ of the gross value added in the manufacturing sector (CSZO, 2020). For these reasons, it is possible to generally conclude that the Czech manufacturing sector is highly exposed to international competition (see also Bič and Vlčková, 2020).

Lastly, because the Czech Republic lacked a clear industrial policy until recently ${ }^{5}$, when the Innovation Strategy was presented (RVVI, 2019), we assume that there was less distortion of market competition than if public funding was systematically channelled to certain industries.

\section{Results and Discussion}

We run our model in R, imposing the condition on the sum of regression coefficients to be equal to unity. ${ }^{6}$ Our estimates for the elasticity are shown in Table 4. Due to autocorrelation, we apply the Prais-Winsten Estimator for AR(1) serial correlation. ${ }^{7}$ The procedure recursively estimates the coefficients and the error autocorrelation of the specified model until sufficient convergence of the AR(1) coefficient is reached (Mohr, 2019). We employ our calculations for the price of capital services in Model 1, while we use data from EU-KLEMS for the price of capital services in Model 2. The fact that EU-KLEMS aggregates certain NACE sectors is reflected by merged cells in the columns for Model 2. For these sectors, the results must be interpreted with caution. The biggest differences (column 3 compared to column 4) are for NACE16, NACE19, NACE22 and NACE33. Out of these sectors, only NACE19 does not have an aggregate estimate of price of capital services, but on the other

4 The names of the sectors can be found in the tables in the Results and Discussion section. More detailed statistics on the number of firms per sector can be found in Table 6 .

5 As Vlčková (2017) points out, "industrial policy has been non-existent since the transition". Because programmes to support companies were not successful, the Czech Republic focused rather on attracting foreign investments and building the necessary infrastructure, in order to increase Czech competitiveness.

6 Using the offset argument of the $\operatorname{lm}($ ) function in the package "stats".

7 Using the prais_winsten function in the package "prais" (Mohr, 2019). 
hand, this sector reports the second-lowest number of firms in 2018 (26), which might bias the results. The estimates in column 5 should be taken as a robustness check rather than main results. Therefore, in our further analysis, we will focus on the results in column 4.

Our estimate for the aggregate elasticity in the manufacturing is 0.659 , which suggests capital and labour are gross complements. Our results are close to what Oberfield and Raval (2014) estimated based on microdata for manufacturing firms (they found a value of 0.75 in 2007). We reject the Cobb-Douglas function, which is consistent with many previous results (Antras, 2004; Klump et al., 2007; Leon-Ledesma et al., 2010, etc.). As discussed previously, the aggregate elasticity seems to be higher than firm-level or industry-level estimates; therefore, the fact that our estimate is higher that the aggregate $\sigma$ for the Czech Republic obtained by Szomolányi et al. (2017) could be slightly surprising. The level of detail might play a certain role in this sense; Gallaway et al. (2003), for instance, assessed the elasticity at SIC22 and found significant differences between 4-digit and 3-digit level estimates.

Empirical estimations of industry-level $\sigma$ support the complementarity between labour and capital (Young, 2013; Herrendorf et al., 2015; Chirinko and Mallick, 2017). Claro (2002) estimated industry-level elasticity for a set of 28 countries and found values near unity, but he adopted a Hicks-neutral approach, which, as discussed earlier, causes a bias of $\sigma$ towards unity. Herrendorf et al. (2015) estimated $\sigma$ at three main sector levels (agriculture, manufacturing and services) in the USA and obtained values over 1 for agriculture and around 0.8 for the other two sectors. Young (2013) and Chirinko and Mallick (2017) estimated $\sigma$ for 35 industries in the USA and found values below 0.5 for most industries. Table 4 summarizes our estimates both before and after applying the Prais-Winsten Estimator.

We obtain sector-level estimates of the elasticity between 0.192 and 0.942 . The highest value is for NACE12 (Manufacture of beverages), and the lowest for NACE15 (Manufacture of leather and related products). Sectors with a high share in the Czech GVA (NACE22, $25,27,28,29)$ have rather low elasticities, around 0.35 for all the mentioned sectors except NACE25, for which we obtained an estimate of 0.613 .

Before comparing our results with industry-level estimates from other studies, we must highlight several important differences and other aspects. Firstly, the sensitivity to methodology and data is high (Young, 2013; Antras, 2004). According to some authors, the estimates are influenced especially by the price of capital services (Berndt, 1976; Inklaar, 2008). Secondly, the period is important: short-term elasticity seems to be lower than long-term estimates (Balistreti et al., 2003). Thirdly, differences in classifications, especially between US and EU data, also limit the comparison of the results, and fourthly, country specifics are very important. The Czech Republic is a small open economy on a post-transition path. This should lead to lower estimates for the Czech Republic. Some industries in the Czech Republic report a lower number of companies, therefore being potentially less stable. 
Table 4: Estimation results

\begin{tabular}{|c|c|c|c|c|}
\hline \multirow{2}{*}{$\begin{array}{l}\text { NACE-2 sector } \\
(1)\end{array}$} & \multicolumn{2}{|c|}{$\begin{array}{l}\text { Before applying } \\
\text { the Prais-Winsten } \\
\text { Estimator }\end{array}$} & \multicolumn{2}{|c|}{$\begin{array}{l}\text { After applying } \\
\text { the Prais-Winsten } \\
\text { Estimator }\end{array}$} \\
\hline & (2) & (3) & (4) & (5) \\
\hline & Model 1 & Model 2 & Model 1 & Model 2 \\
\hline Manufacturing (NACE 10-33) & $0.782 * * *$ & $0.705^{* * *}$ & $0.659 * * *$ & $0.685 * * *$ \\
\hline Manufacture of food products (NACE10) & $0.702^{* * *}$ & \multirow{3}{*}{$\begin{array}{l}0.744^{* * *} \\
0.617^{* * *} \\
0.884^{* * *}\end{array}$} & $0.519 * * *$ & \multirow{3}{*}{$\begin{array}{l}0.586 * * * \\
0.618 * * * \\
0.852 * * *\end{array}$} \\
\hline Manufacture of beverages (NACE11) & $1.268^{* * *}$ & & $0.889 * * *$ & \\
\hline Manufacture of tobacco products (NACE12) & $1.067^{* * *}$ & & $0.941 * * *$ & \\
\hline Manufacture of textiles (NACE13) & $1.028^{* * *}$ & \multirow{3}{*}{$\begin{array}{l}0.757^{* * *} \\
0.456^{* * *} \\
0.708^{* * *}\end{array}$} & $0.503 * * *$ & \multirow{3}{*}{$\begin{array}{l}0.323^{* *} \\
0.055 \\
0.351^{*}\end{array}$} \\
\hline Manufacture of wearing apparel (NACE14) & $0.404^{* * *}$ & & $0.213^{*}$ & \\
\hline Manufacture of leather and related products (NACE15) & $0.244^{* *}$ & & $0.192 *$ & \\
\hline $\begin{array}{l}\text { Manufacture of wood and products of wood and cork; } \\
\text { except furniture; manufacture of articles of straw and } \\
\text { plaiting materials (NACE16) }\end{array}$ & $0.961^{* * *}$ & \multirow{3}{*}{$\begin{array}{l}0.739^{* * *} \\
0.550^{* * *} \\
0.411^{* * *}\end{array}$} & $0.736 * * *$ & \multirow{3}{*}{$\begin{array}{l}0.444 * * * \\
0.434 * * * \\
0.333^{* *}\end{array}$} \\
\hline Manufacture of paper and paper products (NACE17) & $0.606^{* * *}$ & & $0.474 * * *$ & \\
\hline Printing and reproduction of recorded media (NACE18) & $0.972^{* * *}$ & & $0.485 * * *$ & \\
\hline $\begin{array}{l}\text { Manufacture of coke and refined petroleum products } \\
\text { (NACE 19) }\end{array}$ & $0.470^{* * *}$ & $0.168^{* *}$ & $0.406 * * *$ & 0.077 \\
\hline $\begin{array}{l}\text { Manufacture of chemicals and chemical products } \\
\text { (NACE 20) }\end{array}$ & $0.534^{* * *}$ & $0.458^{* * *}$ & $0.359 * * *$ & $0.259 * *$ \\
\hline $\begin{array}{l}\text { Manufacture of basic pharmaceutical products and } \\
\text { pharmaceutical preparations (NACE 21) }\end{array}$ & $0.285^{* * *}$ & $0.239 * * *$ & $0.568 * * *$ & $0.490 * * *$ \\
\hline Manufacture of rubber and plastic products (NACE 22) & $0.880 * * *$ & \multirow{2}{*}{$\begin{array}{l}0.952^{* * *} \\
0.902^{* * *}\end{array}$} & $0.350 * *$ & $0.877^{* * *}$ \\
\hline $\begin{array}{l}\text { Manufacture of other non-metallic mineral products } \\
\text { (NACE 23) }\end{array}$ & $0.818^{* * *}$ & & $0.515^{* * *}$ & $0.838^{* * *}$ \\
\hline Manufacture of basic metals (NACE 24) & $0.247^{* *}$ & \multirow[t]{2}{*}{$0.468^{* * *}$} & $0.242 * *$ & $0.427^{* *}$ \\
\hline $\begin{array}{l}\text { Manufacture of fabricated metal products, except } \\
\text { machinery and equipment (NACE 25) }\end{array}$ & $0.878^{* * *}$ & & $0.613^{* *}$ & $0.368 * * *$ \\
\hline $\begin{array}{l}\text { Manufacture of computer, electronic and optical } \\
\text { products (NACE 26) }\end{array}$ & $1.128^{* * *}$ & $1.097 * * *$ & $0.810 * * *$ & $0.521 * *$ \\
\hline Manufacture of electrical equipment (NACE 27) & $0.732^{* * *}$ & $0.604^{* * *}$ & $0.370^{* * *}$ & $0.261 * *$ \\
\hline $\begin{array}{l}\text { Manufacture of machinery and equipment n,e,c, } \\
\text { (NACE 28) }\end{array}$ & $0.628^{* * *}$ & $0.613^{* * *}$ & $0.376^{* * *}$ & $0.579 * * *$ \\
\hline $\begin{array}{l}\text { Manufacture of motor vehicles, trailers, and semi- } \\
\text { trailers (NACE 29) }\end{array}$ & $0.942 * * *$ & \multirow{2}{*}{$0.810^{* * *}$} & $0.339 * *$ & $0.406 * * *$ \\
\hline Manufacture of other transport equipment (NACE 30) & $0.362^{* * *}$ & & $0.313 * *$ & $0.650 * * *$ \\
\hline Manufacture of furniture (NACE 31) & $0.546^{* * *}$ & \multirow{3}{*}{$\begin{array}{l}0.491^{* * *} \\
0.830^{* * *} \\
0.682^{* * *}\end{array}$} & $0.369 * * *$ & $0.400 * * *$ \\
\hline Other manufacturing (NACE 32) & $1.188^{* * *}$ & & $0.435 *$ & $0.556 * * *$ \\
\hline $\begin{array}{l}\text { Repair and installation of machinery and equipment } \\
\text { (NACE 33) }\end{array}$ & $0.931 * * *$ & & $0.845^{* * *}$ & $0.448 * * *$ \\
\hline
\end{tabular}

Source: Authors' own calculations 
Despite these limitations, we try to compare our estimates with other results at the industry level. The results are presented in Table 5. Balistreti et al. (2003) estimate longterm and short-term elasticities but do not take into account biased technological progress; Claro (2002) uses panel data for 28 industries in 30 countries, which enables us to make a rough international comparison; however, he did not include the Czech Republic in his dataset. The correspondence of industries is not always perfect, the other studies use SIC codes and sometimes different aggregation (see merged cells in Table 5).

The estimates are highly heterogenous across countries and sectors. We will therefore investigate factors that could influence the estimates for the Czech Republic. The first factor is the transitional path of the Czech economy. As Lee and Tcha (2004) suggest, estimates for transition economies are rather low: they find a value of 0.495 in Central and Eastern European countries, Baltic States, and the Commonwealth of Independent States. Previous studies for centrally planned economies find even lower estimates; for instance, Weitzman (1970) assessed the elasticity for the Soviet Union between 1950-1966 and found a value of 0.274 . Therefore, our estimate being lower than unity is in line with the relevant literature.

Another factor that influences the elasticity is the openness of the country. Saam (2008) argues that the aggregate elasticity depends on institutions and policy, and that especially trade openness is highly relevant. While the paper does not focus on the direction of the relationship, it does conclude that this relationship is positive under certain conditions. The Czech Republic is a small open economy, with a share of trade in GDP $143 \%$, more than double the world average of $60 \%$ in 2019 (WB, 2020).

Another relevant aspect is the heterogeneity of the labour force. In most models, labour is treated as a homogenous factor of production due to lack of detailed data. However, Fallon and Layard (1975) already showed that the elasticity of highly skilled workers is lower than that of less skilled workers. However, the impact of Industry 4.0 might be different from previous technological transformations in the sense of correlation between level of skills required and job risk level (risk of job being replaced by technology) (see also Fareri et al., 2020). In some countries, such as the USA, the skill mix is more stable than in the Czech Republic, where the workers' skill level increased rapidly after the 1990s. Not only that the share of formal education increased, but overall, there was an influx of know-how stemming from various factors (accelerating technological development in general, increased accessibility of information, but also knowledge linked to incoming FDI, etc.). The share of persons with tertiary education increased from $7.8 \%$ to $19.1 \%$ between 1993 and 2017 (OECD, 2020), the trend being similar in most transition economies. Even though there are studies calculating the elasticity for centrally planned or transition economies, there is no study focusing on the comparison of these countries with developed countries. 
Table 5: Comparison of estimates of elasticity

\begin{tabular}{|c|c|c|c|c|}
\hline NACE-2 sector & $\begin{array}{l}\text { Our estimates } \\
\text { for } \sigma\end{array}$ & $\begin{array}{c}\text { Balistreti } \\
\text { et al. (2003) }\end{array}$ & $\begin{array}{c}\text { Claro } \\
(\mathbf{2 0 0 2 )}\end{array}$ & $\begin{array}{l}\text { Young } \\
(2013)\end{array}$ \\
\hline Manufacturing (NACE 10-33) & $0.659 * * *$ & & & \\
\hline Manufacture of food products (NACE10) & $0.519 * * *$ & \multirow{2}{*}{$\begin{array}{l}-34.6 / \\
-0.034\end{array}$} & 0.76 & \multirow{2}{*}{$0.293^{* *}$} \\
\hline Manufacture of beverages (NACE11) & $0.889 * * *$ & & 0.86 & \\
\hline Manufacture of tobacco products (NACE12) & $0.941 * * *$ & $\begin{array}{c}1.0226^{* *} \\
0.061\end{array}$ & 2.12 & $0.864 * *$ \\
\hline Manufacture of textiles (NACE13) & $0.503 * * *$ & $\begin{array}{l}1.138^{* *} \\
0.052^{*}\end{array}$ & 0.83 & $0.373^{* *}$ \\
\hline Manufacture of wearing apparel (NACE14) & $0.213^{*}$ & $\begin{array}{l}2.051^{* *} \\
0.125^{* *}\end{array}$ & 0.70 & $0.790 * *$ \\
\hline $\begin{array}{l}\text { Manufacture of leather and related products } \\
\text { (NACE15) }\end{array}$ & $0.192 *$ & $\begin{array}{l}-1.532 \\
0.040^{*}\end{array}$ & 0.86 & $0.417^{* *}$ \\
\hline $\begin{array}{l}\text { Manufacture of wood and products of wood and } \\
\text { cork; except furniture; manufacture of articles } \\
\text { of straw and plaiting materials (NACE16) }\end{array}$ & $0.736 * * *$ & $\begin{array}{l}1.120^{* *} \\
0.208^{* *}\end{array}$ & $0.71^{*}$ & $0.394^{* *}$ \\
\hline Manufacture of paper and paper products (NACE17) & $0.474 * * *$ & $\begin{array}{l}0.907 * * \\
0.057 * *\end{array}$ & 0.80 & $0.373^{* *}$ \\
\hline $\begin{array}{l}\text { Printing and reproduction of recorded media } \\
\text { (NACE18) }\end{array}$ & $0.485^{* * *}$ & $\begin{array}{l}1.510^{* *} \\
0.084^{* *}\end{array}$ & $0.68^{*}$ & $0.352^{* *}$ \\
\hline $\begin{array}{l}\text { Manufacture of coke and refined petroleum products } \\
\text { (NACE 19) }\end{array}$ & $0.406 * * *$ & $\begin{array}{c}76.3 \\
0.020^{* *}\end{array}$ & $\begin{array}{l}0.92- \\
1.08\end{array}$ & $0.762^{* *}$ \\
\hline $\begin{array}{l}\text { Manufacture of chemicals and chemical products } \\
\text { (NACE 20) }\end{array}$ & $0.359 * * *$ & $1.448^{* *}$ & \multirow{2}{*}{0.80} & \multirow{2}{*}{$0.613^{* *}$} \\
\hline $\begin{array}{l}\text { Manufacture of basic pharmaceutical products and } \\
\text { pharmaceutical preparations (NACE 21) }\end{array}$ & $0.568 * * *$ & $0.046^{* *}$ & & \\
\hline $\begin{array}{l}\text { Manufacture of rubber and plastic products } \\
\text { (NACE 22) }\end{array}$ & $0.350 * *$ & $0.806^{* *}$ & $\begin{array}{l}0.59^{* *} \\
-0.66^{*}\end{array}$ & $0.267^{* *}$ \\
\hline $\begin{array}{l}\text { Manufacture of other non-metallic mineral products } \\
\text { (NACE 23) }\end{array}$ & $0.515 * * *$ & $\begin{array}{l}0.501^{* *} \\
0.066^{* *}\end{array}$ & $\begin{array}{c}0.63^{*} \\
-0.96 \\
\end{array}$ & $0.366^{* *}$ \\
\hline Manufacture of basic metals (NACE 24) & $0.242 * *$ & $\begin{array}{l}0.533^{* *} \\
0.081^{* *}\end{array}$ & $\begin{array}{r}0.66 \\
-0.91 \\
\end{array}$ & $0.576^{* *}$ \\
\hline $\begin{array}{l}\text { Manufacture of fabricated metal products, except } \\
\text { machinery and equipment (NACE 25) }\end{array}$ & $0.613 * *$ & $\begin{array}{l}1.393^{* *} \\
0.113^{* *}\end{array}$ & 0.91 & $0.441^{* *}$ \\
\hline $\begin{array}{l}\text { Manufacture of computer, electronic and optical } \\
\text { products (NACE 26) }\end{array}$ & $0.810 * * *$ & \multirow{2}{*}{$\begin{array}{c}3.736 \\
0.075^{* *}\end{array}$} & & \multirow[t]{2}{*}{$0.292^{* *}$} \\
\hline Manufacture of electrical equipment (NACE 27) & $0.370 * * *$ & & $0.69^{*}$ & \\
\hline $\begin{array}{l}\text { Manufacture of machinery and equipment n,e,c, } \\
\text { (NACE 28) }\end{array}$ & $0.376 * * *$ & $\begin{array}{l}0.815^{* *} \\
0.226^{* *}\end{array}$ & 0.96 & $0.597^{* *}$ \\
\hline $\begin{array}{l}\text { Manufacture of motor vehicles, trailers, and semi- } \\
\text { trailers (NACE 29) }\end{array}$ & $0.339 * *$ & $\begin{array}{l}0.400^{* *} \\
0.047^{* *}\end{array}$ & \multirow{2}{*}{0.88} & $0.377^{* *}$ \\
\hline Manufacture of other transport equipment (NACE 30) & $0.313 * *$ & $\begin{array}{l}0.322 \\
0.012 \\
\end{array}$ & & $0.671^{* *}$ \\
\hline Manufacture of furniture (NACE 31) & $0.369 * * *$ & $\begin{array}{l}1.007^{* *} \\
0.097^{* *}\end{array}$ & 0.81 & $0.215^{* *}$ \\
\hline Other manufacturing (NACE 32) & $0.435 *$ & $\begin{array}{l}1.684^{*} \\
0.054^{*}\end{array}$ & 1.38 & 0.038 \\
\hline $\begin{array}{l}\text { Repair and installation of machinery and equipment } \\
\text { (NACE 33) }\end{array}$ & $0.845 * * *$ & & & \\
\hline
\end{tabular}

Source: Authors' own calculations; Balistreti et al. (2003); Claro (2002); Young (2013) 
Another limitation is the assumption of the dynamics of the elasticity in time. Papers adopting a CES function assume that is constant in time. De La Grandville and Solow (2017), for instance, show that the elasticity has an increasing tendency in time (16 OECD countries). In our case, this would imply that our estimate of 0.659 is a certain average value and that the current "true" value is higher than 0.659 (and was accordingly lower than 0.659 in the past). The Czech Republic's transition path seems to support this time-varying hypothesis, as values for transition countries are generally low.

The elasticity value has certain policy implications. There is strong empirical evidence of relevance of for tax policies, which are envisioned to boost private investment. Changes in tax policies, which influence the price of capital, strongly influence firm behaviour (Chirinko, 2002). The higher the elasticity, the bigger the impact of increasing tax rates on investments of firms, and vice versa: decreasing tax burden would boost private investment. Knowing that $\sigma$ varies across industries, industry-level impacts of tax adjustments will also vary even if the tax policy is aiming at all industries. In our case, changes in the taxation policy would most affect NACE11-12 (Beverages and tobacco products), NACE16 (Wood and products of wood and cork), NACE26 (Electronics industry) and NACE33 (Repair and installation of machinery and equipment). Seen from a different perspective, tax adjustments should not impact very much on the core industries of the Czech manufacturing sector. This is, however, a very strong statement and it requires a much more systematic assessment.

Alvarez-Cuadrano et al. (2017) discuss the structural changes in the economy and argue that industries with a higher elasticity substitute labour with capital, so labour is released and can be used in industries with a lower elasticity. This approach to structural changes is relatively new in the literature; the cited paper focuses on the agricultural sector, but similar conclusions could be applied to other sectors.

Table 6 presents additional details on the manufacturing sectors: the numbers of active firms and their time trend, the share of labour costs in GVA and its time trend and the share of each sector in the manufacturing sector GVA as a size measure.

There is no clear link between the value of elasticity and the number of companies in the industry. At a theoretical level, the higher the competition in the sector, the more flexible the companies could be. On the other hand, excessive competition could lead to firms' lower profits and therefore limit investment. Figure 2 is a visualization of three indicators from Table 6. If we look at the share of labour income in GVA, it appears that sectors with high labour costs tend to have lower values of $\sigma$ and vice-versa. This is against the intuition that companies facing increasing costs of inputs should switch to cheaper inputs. In other words, the higher the labour costs, the higher the elasticity should be. Among the biggest sectors, NACE25 is a certain exception in this sense, while NACE26 seems to have a higher elasticity "despite" not experiencing high labour costs. 
The electronics sector, however, is specific in the Czech Republic, as it has a relatively low share of domestic value added in the total exported value added and it is not considered to have good prospects in the nearest future (Vlčková, 2018).

Table 6: Selected indicators for manufacturing industries

\begin{tabular}{|c|c|c|c|c|}
\hline NACE-2 sector & $\begin{array}{l}\text { Our estimates } \\
\text { for } \sigma\end{array}$ & $\begin{array}{l}\text { Number of active } \\
\text { firms }\left(2018^{a}\right)\end{array}$ & $\begin{array}{c}\text { Share of labour } \\
\text { costs / GVA } \\
(1995-1997 \\
\text { vs 2017-2019) }\end{array}$ & $\begin{array}{l}\text { Share in total } \\
\text { GVA (2019) }\end{array}$ \\
\hline NACE10-33 & $0.659 * * *$ & $180193 \uparrow$ & $49-53 \%$ & $100 \%$ \\
\hline NACE10 & $0.519 * * *$ & $8463 \uparrow$ & $49-62 \%$ & $5.3 \%$ \\
\hline NACE11 & $0.889 * * *$ & $2412 \uparrow$ & $38-32 \%$ & $2.4 \%$ \\
\hline NACE12 & $0.941 * * *$ & $7 \uparrow$ & $29-18 \%$ & $0.6 \%$ \\
\hline NACE13 & $0.503 * * *$ & $2289 \downarrow$ & $65-65 \%$ & $1.2 \%$ \\
\hline NACE14 & $0.213^{*}$ & $13684 \uparrow$ & $66-53 \%$ & $0.8 \%$ \\
\hline NACE15 & $0.192 *$ & $621 \downarrow$ & $74-65 \%$ & $0.2 \%$ \\
\hline NACE16 & $0.736 * * *$ & $29135 \uparrow$ & $56-42 \%$ & $2.5 \%$ \\
\hline NACE17 & $0.474 * * *$ & $1003 \uparrow$ & $37-47 \%$ & $1.9 \%$ \\
\hline NACE18 & $0.485 * * *$ & $9610 \uparrow$ & $62-55 \%$ & $1.2 \%$ \\
\hline NACE19 & $0.406 * * *$ & $\mathrm{n} 28 \uparrow$ & $27-52 \%$ & $0.1 \%$ \\
\hline NACE20 & $0.359 * * *$ & $1771 \uparrow$ & $30-40 \%$ & $3.8 \%$ \\
\hline NACE21 & $0.568 * * *$ & $93 \uparrow$ & $15-35 \%$ & $1.6 \%$ \\
\hline NACE22 & $0.350 * *$ & $3595 \downarrow$ & $57-54 \%$ & $7.2 \%$ \\
\hline NACE23 & $0.515 * * *$ & $6024 \downarrow$ & $46-55 \%$ & $4.6 \%$ \\
\hline NACE24 & $0.242 * *$ & $1064 \downarrow$ & $43-68 \%$ & $2.8 \%$ \\
\hline NACE25 & $0.613 * *$ & $47710 \uparrow$ & $54-57 \%$ & $11.7 \%$ \\
\hline NACE26 & $0.810 * * *$ & $3203 \downarrow$ & $40-34 \%$ & $5.6 \%$ \\
\hline NACE27 & $0.370 * * *$ & $11,190 \downarrow$ & $55-60 \%$ & $7.7 \%$ \\
\hline NACE28 & $0.376 * * *$ & $4833 \downarrow$ & $53-69 \%$ & $8.5 \%$ \\
\hline NACE29 & $0.339 *$ & $1089 \downarrow$ & $44-46 \%$ & $21.1 \%$ \\
\hline NACE30 & $0.313 * *$ & $836 \uparrow$ & $77-60 \%$ & $1.9 \%$ \\
\hline NACE31 & $0.369 * * *$ & $5698 \downarrow$ & $57-57 \%$ & $1.3 \%$ \\
\hline NACE32 & $0.435^{*}$ & $9684 \uparrow$ & $72-60 \%$ & $2.3 \%$ \\
\hline NACE33 & $0.845 * * *$ & $16153 \uparrow$ & $62-53 \%$ & $3.8 \%$ \\
\hline
\end{tabular}

a The arrows in the column "Number of active firms" indicate the trend for the previous years.

Source: Authors' own calculations; CSZO, 2020; MPO, 2020 


\section{Figure 2: Visualization of labour costs and elasticities across sectors}

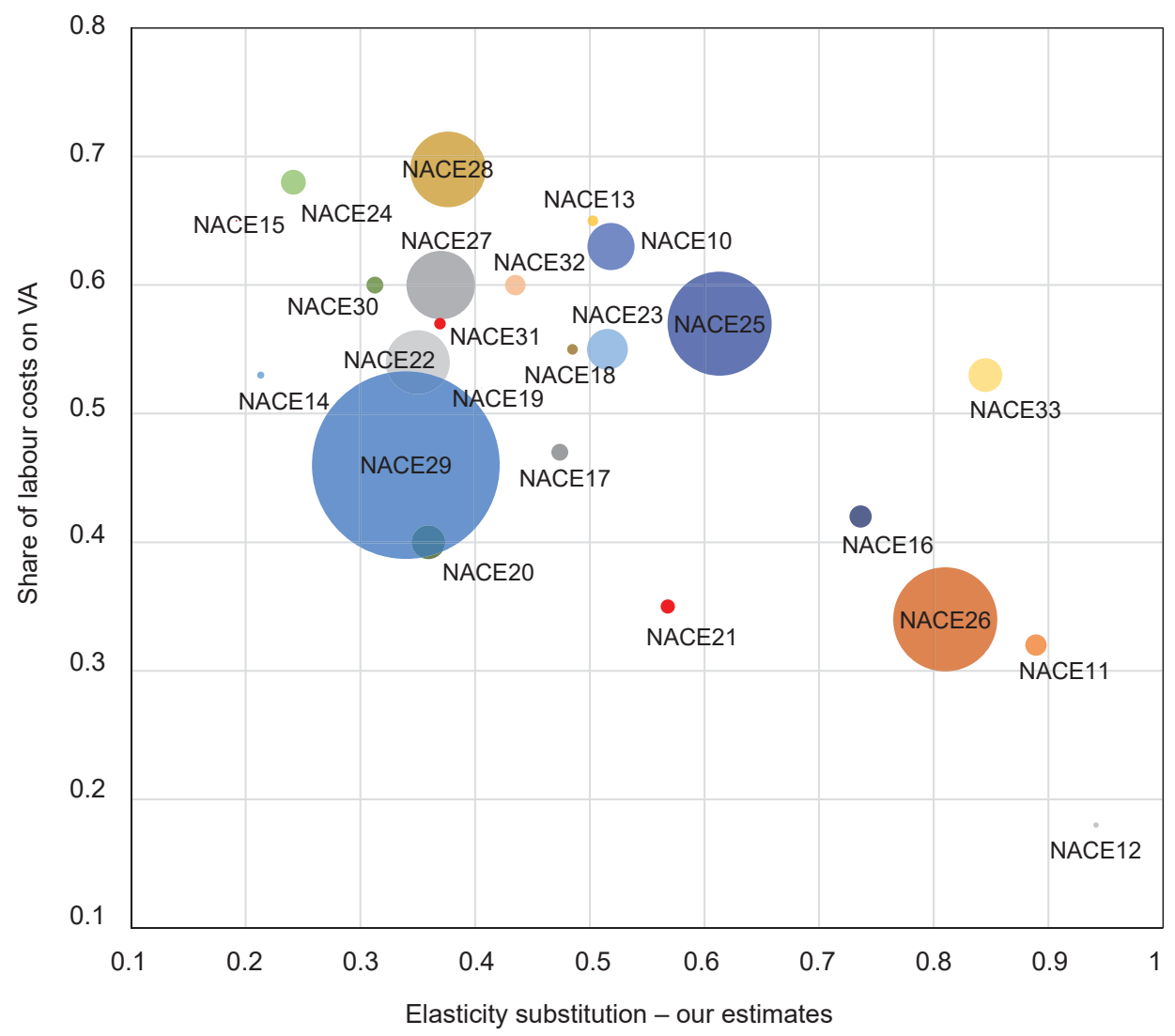

Note: The size of the bubbles indicates the share of the industry GVA in the total manufacturing sector GVA.

Source: Authors' own calculations; CSZO, 2020

One possible explanation is the direction of the technological bias. As shown in Table 2, a combination of $\sigma<1$ and capital-augmenting technological progress can lead to an increase in the income share of labour. Our data show that this is not the case, as the dynamic of labour-augmenting technological progress is higher than that of capital-augmenting progress (Figure 3). This is not surprising, knowing that the Czech Republic is only a moderate innovator with rather modest dynamics within the moderate innovators group (EC, 2020). 
Figure 3: Evolution of capital- and labour-augmenting technological progress (logged values normalized to 2015)

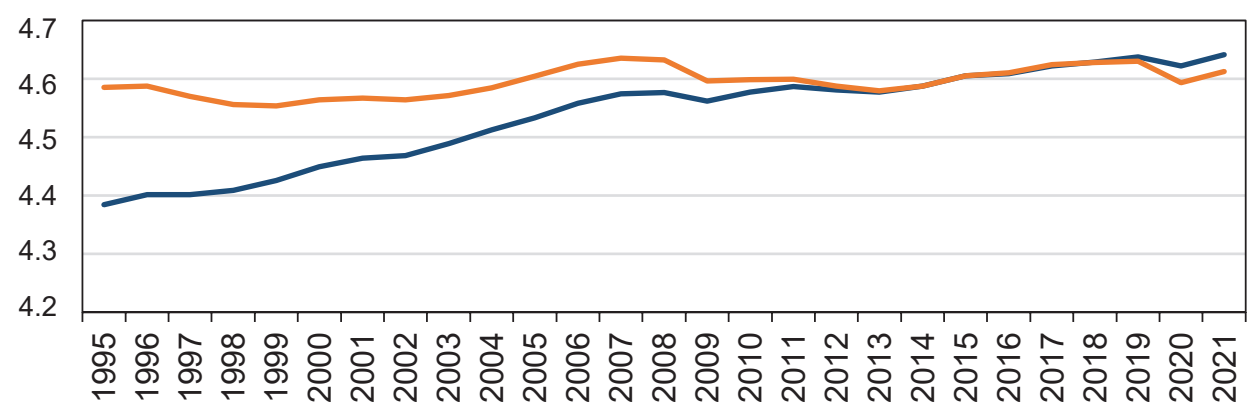

Source: AMECO, 2020

\section{Conclusion}

In our paper, we estimate the elasticity of substitution between capital and labour by using a CES production function for the Czech Republic, for NACE2 industry-level data covering the period 1995-2019. Our estimates are between 0.192 and 0.942 , with an aggregate value of 0.659 for the manufacturing sector. While it is difficult to compare the estimates across countries and sectors, our estimates seem to be in line with the bulk of the literature. Furthermore, our rather low estimates correspond to the literature on transition countries. We apply one of the newer approaches, which adopt a biased technological progress. Furthermore, we take advantage of the data availability and allow for the technological progress to be time-varying and not constant. On the other hand, we had to assume that all sectors experience the same technological progress, because sector-level data are not available. This could be true to a certain extent, because many technologies are currently implemented in all sectors (big data, automation, etc.).

Our results suggest several implications for the Czech Republic. Even if facing high and increasing costs of labour and labour-augmenting technological progress, the values of the elasticities in the core manufacturing sectors are quite low. One possible explanation is that our values are underestimated. Evidence from the literature reports lower values of elasticity for transition economies. It might be the case that the Czech Republic, as a post-transformation country, currently has higher values of elasticities than the ones we find, because we assume that they are constant in time.

Another possibility is that the Czech Republic is still facing problems linked to the transformation process: it belongs to the group of moderate innovators in the EU, 
the share of R\&D expenditures is rather modest (only $1.79 \%$ of GDP compared to $2.78 \%$ in the USA and 2.06 in the EU28 (Eurostat, 2020).

The results of our paper open further questions. Is a time-variant approach to estimating the elasticity of substitution more appropriate for the Czech Republic, considering it is a post-transition country? This might be a direction for further research in the field. Another issue is how the increasing labour costs, labour-augmenting technological progress and low values of elasticity can be explained and what the policy implications are. As one of the latest country reports argue (Hnát et al., 2020), the Czech Republic should develop a smart specialization strategy, which identifies and supports core industries in terms of size, dynamics and future potential. More information about the flexibility of these sectors in terms of ability to replace factors of production would be very useful.

\section{References}

Acemoğlu, D. (2003). Labor- and Capital- augmenting Technical Change. Journal of the European Economic Association, 1(1), 1-37, https://doi.org/10.3386/w7544

Alvarez-Cuardado, F., Van Long, N., Poschke, M. (2017). Capital-Labor Substitution, Structural Change and Growth. Theoretical Economics, 12(3), 1229-1266, https://doi.org/10.3982/ TE2106

AMECO (2020). Database. Bruxelles: European Commission, Economic and Financial Affairs. [Retrieved 2020-06-xx] Available at: https://ec.europa.eu/economy_finance/ameco/ user/serie/SelectSerie.cfm

Antras, P. (2004). Is the US Aggregate Production Function Cobb-Douglas? New Estimates of the Elasticity of Substitution. Contributions in Macroeconomics, 4(1), https://doi.org/10.2202/1534-6005.1161

Arrow, K. J., Chenery, H. H., Minhas, B. S., et al. (1961). Capital-Labor Substitution and Economic Efficiency. The Review of Economics and Statistics, 43(3), 225-250, https://doi.org/10.2307/1927286

Balistreti, E. J., McDaniel, C. A., Wong, E. V. (2003). An Estimation of US Industry Level Capital-labor Substitution Elasticities: Support for Cobb-Douglas. The North American Journal of Economics and Finance, 14(3), 343-356, https://doi.org/10.1016/ S1062-9408(03)00024-X

Berndt, E. R. (1976). Reconciling Alternative Estimates of the Elasticity of Substitution. The Review of Economics and Statistics, 58(1), 59-68, https://doi.org/10.2307/1936009

Berthold, N., Fehn, R., Thode, E. (2002). Falling Labour Share and Rising Unemployment: Long-run Consequences of Institutional Shocks? German Economic Review, 3(4), 431-459, https://doi.org/10.1111/1468-0475.00067 
Bič, J., Vlčková, J. (2020). Industry 4.0 and FDI. Czechia. Country study prepared in the project No. 21920068 , "Effects of Industry 4.0 on FDI in the Visegrád countries" financed by the Visegrad Fund. Available at: https://industry40fdi.files.wordpress.com/2020/10/ czechia-report.pdf

Cantore, C. M., Levine, P., Pearlman, J., et al. (2015). CES Technology and Business Cycle Fluctuations. Journal of Economic Dynamics and Control, 61(C), 133-151, https://doi.org/10.1016/j.jedc.2015.09.006

Chirinko, R. S. (2002). Corporate Taxation, Capital Formation, And the Substitution Elasticity Between Labor and Capital. National Tax Journal, 55(2), 339-355, https://doi.org/10.17310/ ntj.2002.2.07

Chirinko, R. S. (2008). $\sigma$ : The Long and Short of It. Journal of Macroeconomics, 30(2), 671-686, https://doi.org/10.1016/j.jmacro.2007.10.010

Chirinko, R. S., Mallick, D. (2017). The Substitution Elasticity, Factor Shares, and the Low-Frequency Panel Model. American Economic Journal, 9(4), 225-253, https://doi.org/10.1257/mac.20140302

Claro, S. (2002). A Cross-Country Estimation of Elasticity of Substitution between Labor and Capital in Manufacturing Industries. Cuadernos de Economía, 120(40), 239-257, https://doi.org/10.4067/S0717-68212003012000003

CSZO (2020). Database of National Accounts. Prague: Czech Statistical Office. [Retrieved 2020-06-xx] Available at: http://apl.czso.cz/pll/rocenka/rocenka.indexnu?mylang=EN

de La Grandville, O. (1989). In Quest of the Slutsky Diamond. The American Economic Review, 79(3), 468-841.

de La Grandville, O., Solow, R. M. (2017). Capital-Labour Substitution and Economic Growth. Economic Growth - A United Approach, 114-154, https://doi.org/10.1017/978131 6335703.010

Duffy, J., Papageorgiou, C. (2000). A Cross-Country Empirical Investigation of the Aggregate Production Function Specification. Journal of Economic Growth, 5, 87-120, https://doi.org/10.1023/A:1009830421147

Easterly, W., Fisher, S. (1995). The Soviet Economic Decline. The World Bank Economic Review, 9(3), 341-371, https://doi.org/10.1093/wber/9.3.341

Eurostat (2020). R\&D Expenditure. Luxembourg: Eurostat. [Retrieved 2020-08-xx] Available at: https://ec.europa.eu/eurostat/statistics-explained/index.php/R_\%26_D_expenditure

EU-KLEMS (2020). Growth and productivity accounts. WIIW. [Retrieved 2020-06-xx]. Available at: https://euklems.eu/download/

Fallon, P. R., Layard, P. R. G. (1975). Capital-skill Complementarity, Income Distribution, and Output Accounting. Journal of Political Economy, 83(2), 279-302, https://doi.org/10.1086/260323

Fareri, S., Fantoni, G., Chiarello, F., et al. (2020). Estimating Industry 4.0 Impact on Job Profiles and Skills Using Text Mining. Computers in Industry, 118, https://doi.org/10.1016/j. compind.2020.103222 
Gallaway, M. P., McDaniel, C. A., Rivera, S. A. (2003). Short-run and Long-run Industry-level Estimates of US Armington Elasticities. The North American Journal of Economics and Finance, 14(1), 49-68, https://doi.org/10.1016/S1062-9408(02)00101-8

Gechert, S., Havranek, T., Irsova, Z., et al. (2019). Death to the Cobb-Douglas Production Function? A Quantitative Survey of the Capital-Labor Substitution Elasticity. EconStor Preprints 203136. Kiel: ZBW - Leibniz Information Centre for Economics.

Herrendorf, B., Herrington, C., Valentinyi, A. (2015). Sectoral Technology and Structural Transformation. American Economic Journal, 7(4), 104-133, https://doi.org/10.1257/ mac.20130041

Hnát, P., Jiránková, M., Stuchlíková, Z., et al. (2020). Targeting of the Investment Support in the Czech Republic with Regard to the Expected Impacts of Technological Changes. Second Annual Report. Prague: University of Economics and Business, Available at: https://kmev.vse.cz/wp-content/uploads/TACR_Cl_2020.pdf

Inklaar, R. (2008). The Sensitivity of Capital Service Measurement: Measure All Assets and the Cost of Capital. Review of Income and Wealth, 56(2), 389-412, https://doi.org/10.1111/j.1475-4991.2010.00383.x

Jalava, J., Pohjola, M., Ripatti, A., et al. (2006). Biased Technical Change and Capital-Labour Substitution in Finland, 1902-2003. Topics in Macroeconomics, 6(1), 1328-1328

Karabarbounis, L., Neiman, B. (2014). The Global Decline of the Labor Share. The Quarterly Journal of Economics, 129(1), 61-103, https://doi.org/10.1093/qje/qjt032

Klump, R., McAdam, P., Willman, A. (2007). Factor Substitution and Factor-Augmenting Technical Progress in the United States: A Normalized Supply-Side System Approach. The Review of Economics and Statistics, 89(1), 183-192, https://doi.org/10.1162/rest.89.1.183

Klump, R., McAdam, P., Willman, A. (2008). Unwrapping Some Euro Area Growth Puzzles: Factor Substitution, Productivity and Unemployment. Journal of Macroeconomics, 30(2), 645-666, https://doi.org/10.1016/j.jmacro.2007.06.005

Klump, R., McAdam, P., Willman, A. (2012). The Normalized CES Production Function: Theory and Empirics. Journal of Economic Surveys, 26(5), 769-799, https://doi.org/10.1111/j.1467-6419.2012.00730.x

Knoblach, M., Rosler, M., Zwerschke, P. (2020). The Elasticity of Factor Substitution Between Capital and Labor in the U.S. Economy: A Meta-Regression Analysis. Oxford Bulletin of Economics and Statistics, 82(1), 62-82, https://doi.org/10.1111/obes.12312

Kreuser, F., Burger, R., Rankin, N. (2015). The Elasticity of Substitution and Labour Displacing Technical Change in Post-apartheid South Africa. UNU-WIDER. Helsinki Working Paper No. 2015/101, https://doi.org/10.35188/UNU-WIDER/2015/990-9

Lee, M., Tcha, M. (2004). The Color of Money: The Effects of Foreign Direct Investment on Economic Growth in Transition Economies. Review of World Economics, 140(2), 211-229, https://doi.org/10.1007/BF02663646

León-Ledesma, M. A., McAdam, P., Willman, A. (2010). Identifying the Elasticity of Substitution with Biased Technical Change. American Economic Review, 100(4), 1330-1357, https://doi.org/10.1257/aer.100.4.1330 
Mallick, D. (2012). The Role of the Elasticity of Substitution in Economic Growth: A Crosscountry Investigation. Labour Economics, 19(5), 682-694, https://doi.org/10.1016/j. labeco.2012.04.003

Mohr, F. X. (2019). Package 'prais': Prais-Winsten Estimator for AR(1) Serial Correlation. Available at: https://cran.r-project.org/web/packages/prais/index.html

MPO (2020). Panorama of the Manufacturing Industry. Prague: Ministry of Industry and Trade [Retrieved 2020-08-xx ]Available at: https://www.mpo.cz/en/industry/ manufacturing-industry/panorama-of-the-manufacturing-industry/

Oberfield, E., Raval, D. (2014). Micro Data and Macro Technology. National Bureau of Economic Research. Cambridge, MA Working Paper No. 20452, https://doi.org/10.3386/w20452

OECD (2020). Population with Tertiary Education. Paris: Organisation for Economic Co-operation and Development. [Retrieved 2020-05-xx] Available at: https://data.oecd.org/eduatt/ population-with-tertiary-education.htm

Raurich, X., Sala, H., Sorolla, V. (2012). Factor Shares, the Price Markup, and the Elasticity of Substitution Between Capital and Labor. Journal of Macroeconomics, 34(1), 181-198, https://doi.org/10.1016/j.jmacro.2011.09.004

RVVI (2019). Inovační strategie České republiky 2019-2030. Prague: Rada pro výzkum, vývoj a inovace. [Retrieved 2021-03-xx] Available at: https://www.vlada.cz/assets/urad-vlady/ poskytovani-informaci/poskytnute-informace-na-zadost/Priloha_1_Inovacni-strategie.pdf

Saam, M. (2008). Openness to Trade as a Determinant of the Macroeconomic Elasticity of Substitution. Journal of Macroeconomics, 30(2), 691-702, https://doi.org/10.1016/j. jmacro.2007.06.006

Sala, H., Trivín, P. (2018). The Effects of Globalization and Technology on the Elasticity of Substitution. Review of World Economics, 154(3), 617-647, https://doi.org/10.1007/ s10290-018-0315-7

Szomolányi, K., Lukáčik, M., Lukáčiková, A. (2017). Estimation of the Elasticity of the Substitution in the Czech Economy Using the Low-Pass Filter Model. The International Scientific Conference INPROFORUM 2017, pp. 379-382. Available at: http://ocs.ef.jcu.cz/index.php/ inproforum/INP2017/paper/view/973

Vlčková, J. (2017). Global Production Networks in Central European Countries: the Case of the Visegrad Group. Prague: Oeconomica Publishing House. ISBN 978-80-245-2197-8, https://doi.org/10.18267/pu.2017.vlc.2197.8

Vlčková, J. (2018). Visegrad Countries in Global Production Networks: Value Creation, Control and Capture. Geographia Polonica, 91(4), 427-448, https://doi.org/10.7163/GPol.0129

WB (2020). Exports of Goods and Services (\% GDP). Washington, D.C.: World Bank. [Retrieved 2020-09-xx] Available at: https://data.worldbank.org/indicator/NE.EXP.GNFS.ZS

Weitzman, M. L. (1970). Soviet Postwar Economic Growth and Capital-Labor Substitution. The American Economic Review, 60(4), 676-692.

Young, A. T. (2013). U.S. Elasticities of Substitution and Factor Augmentation at the Industry Level. Macroeconomic Dynamics, 17(4), 861-897, https://doi.org/10.1017/ s1365100511000733 